\title{
Prāsangika's Semantic Nominalism: Reality is Linguistic Concept
}

\author{
Sonam Thakchoe
}

Published online: 11 July 2012

(C) Springer Science+Business Media B.V. 2012

\begin{abstract}
Buddhist semantic realists assert that reality is always non-linguistic, beyond the domain of conceptual thought. Anything that is conceptual and linguistic, they maintain, cannot be reality and therefore cannot function as reality. The Prāsangika however rejects the realist theory and argues that all realities are purely linguistic_-just names and concepts_and that only linguistic reality can have any causal function. This paper seeks to understand the Prāsangika's radical semantic nominalism and its philosophical justifications by comparing and contrasting it with the realistic semantic theories.
\end{abstract}

Keywords Philosophy of language - Semantic theory $\cdot$ Nominalism · Ontology · Universals · Unique Particulars

\section{Introduction}

In his Treatise on the Essence of True Eloquence (Legs bshad snying po) Tsongkhapa blo bzang grags pa characterises the philosophy of language in the Prāsangika works of Nāgārjuna, ${ }^{1}$ Buddhapālita and Candrakīti to be distinctive. There Tsongkhapa claims that the Prāsangika posits all realities through the force of linguistic convention: language and ontology (rnam gzhag) are understood to be mutually embedded within each other, such that "realities (yod pa) are merely (tsam) names (ming), terms (brda) and linguistic conventions (tha snyad)." ${ }^{2}$ According to

\footnotetext{
${ }^{1}$ The inclusion of Nāgārjuna in the Prāsangika camp is to acknowledge the chronology of the key arguments associated with the semantic nominalism as they are first advanced in the works of Nāgārjuna.

2 Tsongkhapa, Gsung 'bum 67b, DNLS (1997, 199-201-2) thal'gyur bas ni ... yod pa rnams kyang ming dang brda dang tha snyad tsam du lan mang por bshad pa'i phyir ro, ,
}

S. Thakchoe (西)

University of Tasmania, Hobart, TAS, Australia

e-mail: Sonam.thakchoe@utas.edu.au 
Tsongkhapa, central to the Prāsangika's semantic theory is the thesis is that reality constitutes merely linguistic concepts, and merely linguistic concepts are causally efficient.

Language, according to the Prāsangika, is always meaningful, although it always lacks intrinsic meaning, for it does not have any intrinsically real meaning apart from what social conventions ascribed it to mean. The real linguistic meaning is nowhere to be found: it is neither in words nor in sentences not even in its referent. However since language is dependently originated, there can be no language without its meaning, likewise there is no meaning without language. It also argues that there is no such thing as objectively and uniquely real referent. All referents are always and necessarily linguistic and therefore conceptually constructed. Linguistic referent is already embedded in language; even so, is language already embedded in ontology. Neither language nor ontology has priority over each other.

The Prāsangika therefore disagrees fundamentally with Dignāga-Dharmakīrtian idea that reality is uniquely (svalakṣaṇa) and intrinsically (svabhāva) given to language, and that language in and of itself is meaningless. The Dignāga-Dharmakīrtian realistic nominalism or conceptualism operates on the presumption that either language has priority over ontology or ontology has priority over language. It claims that reality and language stand apart from each other independently and constitutively. The Prāsangika argues that reality is fundamentally a linguistic entity, and it denies any extra-linguistic reality. While on the Dignāga-Dharmakīrtian semantic theory, reality can never be a linguistic entity, it must be an ineffable - extra-linguistic and non-conceptual whereas language is always divorced from reality, operating purely at the conceptual level.

In this study I focus on the works of Candrakīrti, Nāgārjuna and Tsongkhapa and examine the arguments that these philosophers employ to defend the Prāsangika type of semantic nominalism. Here I will explore three key arguments which I believe support Prāsangika's semantic nominalism: (1) that all entities are linguistic concepts; (2) that nirvāna and ultimate truth are linguistic concepts, and (3) that empty concepts are causally efficient.

I belief this is a project worthy of a detailed consideration, for it has very profound implications on the structure of language and ontology that is very different from the main stream Indian Buddhist philosophy. No other Indian and Buddhist schools of thought has ever conceived, advanced and defended systematically such a radical thesis, not even by the Sautrāntrika-Yogācāra who advocates a form of conceptualism which is often described as a form of nominalism.

\section{Realities are Linguistic Concepts}

Apart from the Prāsangika all other Buddhist philosophers propose certain forms of critical semantic realism. The Vaibhașika, Sautrāntika, Yogācāra, including the Svātantrika Madhyamaka, do not rest content with persons or things being merely linguistic conventions or mere concepts. For them the reality of persons and things are much more-they must be unique particulars (svalakṣaṇa) serving as either direct or ultimate referent (in the case Ābhidharmika) or indirect referent (in the case of Sautrāntika-Yogācāra) of the linguistic convention which, they argue, must 
be epistemically warranted through authoritative cognitive processes. This is partly evidenced from a critical approach Ābhidharmika and Sautrāntika-Yogācāra adopt towards the linguistic convention on the basis of which they either deny or posit reality of persons or things.

The semantic realists, for instance, critically analyse the referent "person" in the linguistic expression such as "This person performed this action and experienced this result" by means of asking questions such as "Is this person identical to his own aggregates, or different from the aggregate?" On being critically analysed, if an ontological referent of the person-impartite atomic particles-is discovered, it gives them the linguistic basis for positing the 'person' and the account of person's action and its fruits. On being critically analysed, if no such ontological referent of the person is found, the semantic realists deny the existence of person all together, for, according to them, there is no linguistic basis established analytically for positing person in such cases. ${ }^{3}$ For instance the foundational consciousness is the analytical basis upon which Yogācāra designates person, and the continuum of mental consciousness is the analytical basis upon which Sautrāntrika and Svātantrika designate person.

Likewise for these semantic realists existence is that which is epistemically warranted (pramāna / tshad ma), whereas nonexistence is that which is epistemically unwarranted. In the case of the former the referent of the linguistic expression is verified upon the analysis into the status of the object which is indicated by that linguistic expression. In the case of the latter no referent is verified (rnyed pa'i don med na) upon the analysis into the status of the object which is indicated by the expression of that particular name. ${ }^{4}$

$\bar{A}$ bhidharmika defines distinctive characteristic of things, heat in the case of fire, as their unique particular. The Sautrāntika-Logician defines it as ultimate causal efficiency (don byed nus pa). ${ }^{5}$ The Svātantrika Madhyamika rejects unique particular ultimately, it does however accepts it as a criterion of causal efficiency, conventionally. Candrakīrti's philosophy does not however accept, even conventionally (tha snyad du yang), the presentation of such sort of existence."6

The Prāsangika's assertion is that the critical analysis of the referents of linguistic convention of all phenomena leads to no discovery of any extra-linguistic meaning,

\footnotetext{
${ }^{3}$ Tsongkhapa, Gsung 'bum 65a-65b, DNLS (1997, p. 196):'on ji 'dra zhig tu bzung na rang gi mtshan nyid kyis grub par bzung ba yin zhe na, 'di la thog mar grub mtha' smra ba'i lugs brjod par bya ste, gang zag 'dis las 'di byas so, ,'bras bu 'di myong ngo zhes pa'i tha snyad btags pa la rang gi phung po 'di nyid gang zag yin nam 'on te de dag las don gzhan zhes gang zag gi tha snyad btags pa de'i don btsal te, den gcig pa'i don tha dad la sogs pa'i phyogs gang rung zhig rnyed nas gang zag de 'jog sa byung na las gsog pa po la sogs par 'jog nus la, ma rnyed na 'jog mi nus pas gang zag gi tha snyad btags pa tsam gyis mi tshim par de'i tha snyad gang la btags pa'i btags gzhi de ji ltar yin dpyad cing btsal nas 'jog na gang zag rang gi mtshan nyid kyis grub par [65b] 'jog pa yin te, rang sde bye brag tu smra ba nas dbu ma rang rgyud pa'i bar thams cad kyis de bzhin du 'dod do, ,

${ }^{4}$ Tsongkhapa, Gsung 'bum 65b, DNLS (1997, p. 196): tshad mas grub par 'dod pa thams cad yod par 'jog pa na rang rang gi ming gi tha snyad 'jug pa'i 'jug gzhi'i don de ji 'dra zhig tu grub pa btsal ba na des rnyed pa'i don med na yod par 'jog mi nus pas de las bzlog pa la yod par 'jog go ,

5 Tsongkhapa, Gsung 'bum 65b, DNLS (1997, pp. 196-197): rtog ge'i gzhung nas don byed nus pa kho na la rang mtshan dang, mngon pa'i mdo la sogs par gzhan dang thun mong ma yin par mtshon pa me'i tsha ba lta bu la rang gi mtshan nyid du bshad pa dang, rang gi mtsan nyid kyis grub pa'i rang mtshan ni ches shin tu mi 'dra'o, ,

${ }^{6}$ MA Bden pa gnyis su'ang rang bzhin med pa'i phyir // de dag rtag pa ma yin chad pa'ang min / 6.38cd/
} 
either of their identity or difference, and yet it is appropriate to employ linguistic conventions to address a person by names such as "Yajña" etc. There is no extralinguistic reality / existence (yod) that is established through the force of linguistic conventions or expressions (tha snyad). ${ }^{7}$ Nāgārjuna makes this point: "The Buddha says 'due to the power of linguistic conventions, not on the power of reality (yang dag gis min), are things 'produced,' 'destroyed,' 'exist,' 'do not exist,' 'inferior,' 'mediocre,' 'superior." (ŚSK 1)

Mundane convention does employ linguistic formulations such as "the sprout arises from the seed," etc., but it does it so without the analysis of the object represented by the linguistic convention (tha snyad kyi don). Hence the mundane linguistic convention does not require us to investigate whether a sprout arises from itself or from another or both or causelessly. ${ }^{9}$ For the Prāsangika, argues Tsongkhapa, "'mundane linguistic convention is always non-analytic' ( ma dpyad pa'i jig rten gyi tha snyad kyi don) which means that we define things nonanalytically, and therefore it is inappropriate to critically analyse the person. Hence it is error to define person (gang zag) to be substantially different from the aggregates (phung po las rdzas tha dad pa) or to define person to be the unity of the aggregates, and so on critically. For the mundane practice posit the self and its possessions as they are, as we do ascribe, a "master" and a "slave," even though there is neither intrinsic master nor intrinsic slave..$^{10}$

In Catuhśatakațika Candrakīti argues that realities are "Like the snake which is conceptually imputed on the coiled ropes, the [realities] that exist due to the existence of the concepts ( rtog pa) and do not exist due to the absence of the concepts are indeed not established through their intrinsic nature." ${ }^{11}$ Nāgārjuna's Śñnyatāsaptatikārikā (ŚSK) uses his famous Tathāgata emanations imagery to explain the point. Suppose Bhagvāna-Tathāgata by means of his miraculous powers displays an emanation (sprul pa), suppose that that the emanation in turn generates another emanation. (ŚSK 40)

\footnotetext{
7 Tsongkhapa (DNLS 1997, p. 218): de ltar bdag dang chos rnams kyi tha snyad kyi don btzal ba na gcig dang tha dad sogs cung zad kyang mi rnyed la, 'on kyang mchod sbyin no, , mig go zhes pa sogs kyi tha snyad kyang nges par bya dgos pas tha snyad kyi dbang gis ma bzhag pa'i ngo bo med pa dang, tha snyad kyi dbang gis yod par bzhag pa la 'khor 'das kyi rnam gzhag thams cad chas shin tu 'thad pa'i bden pa gnyis kyi rnam gzhag 'di ni sangs rgyas [74a], ,bskyangs dang zla ba'i zhabs kyis 'phags pa yab sras kyi dgongs pa bkral ba 'grel pa gzhan las khyad zhugs pa'i khyad chos bla na med pa'o, ,

${ }^{8} \mathrm{Dbu}$ ma tsa 24a: gnas pa'am skye 'jig yod med dam, ,dman pa'am mnyam dang khyad par can, ,sangs rgyas 'jig rten snyad dbang gis, ,gsung gi yang dag dbang gis min, ,

9 Tsongkhapa, Gsung 'bum 74a, DNLS (1997, p. 220): dbu ma pas tha snyad du 'jog dgos la 'jig rten pa'i tha snyad ni sa bon las myu gu skye ba sogs kyi rnam gzhag byad kyang tha snyad kyi don de ji ltar yin btsal nas bdag gam gzhan gang las skye ba sogs kyi dpyad pa med pa kho nar 'jog pa yin zhing, 'phags pas kyang da kho na ltar bshad pa'i phyir dang

10 Tsongkhapa, Gsung 'bum 74a-74b, DNLS (1997, p. 220): ma dpyad pa'i 'jig rten gyi tha snyad kyi don ni sngar gang zag 'jog tshul bshad pa ltar lugs 'dis bzhag pa lta snang gi, phung po las rdzas tha dad pa dang phung po tsogs tzam la sogs pa gang zag tu 'jog pa 'jig rten gyi tha snyad kyi don du gtan mi rung ba'i phyir te, bdag dang bdag gi [74b] ba ni 'jig rten na rje khol ltar 'jog pa'i phyir ro, ,

11 Dbu ma Ya: 133a: de'i phyir gang dag rtog pa yod pa kho nas yod pa nyid dang, rtog pa med par yod pa nyid med pa de dag ni gor ma chag par thag pa bsngogs pa la brtags pa'i sbrul ltar rang gi ngo bos ma grub par nges so, ,
} 
Since the original emanation displayed by the Tathāgata itself is empty of intrinsic reality, there is hardly any need to mention that the emanation generated by the emanation is likewise empty. The two [emanations] exist only merely nominally (ming tsam yod pa). Whatever forms they may take (gang ci'ang rung te), they are mere concepts (rtog pa tsam) (ŚSK 41) (emphasis mine). ${ }^{12}$

Nāgārjuna's argument is this. Tathāgata emanations exist merely nominally (ming tsam yod pa) as mere concepts (rtog pa tsam), for they are empty: they do not exist as intrinsically real Tathāgatas. Explaining this argument further Candrakīrti's Śñnayatāsaptativrtti ${ }^{13}$ (ŚSV 41) says that the emanation generated from the emanation displayed by the actual (yang dag pa) Tathāgatā itself is empty, for it lacks Tathāgatā's intrinsic reality (rang bzhin). By this, on Candrakīrti's reading, ${ }^{14}$ the designation "emanations" lacked any real referent or meaning (snying po dang dral ba), for the designata (the aggregates of the emanations) are all devoid of intrinsic reality (rang bzhin dang dral ba). ${ }^{15}$

Nāgārjuna, then, applies the same argument from the Tathāgatā's emanation imagery in order to show the linguistic character of actions and agents, among other entities. "Agent," he says, "is likened to the emanation (sprul pa), its action likened to the emanations displayed by the emanation (sprul pas sprul pa): they have mere existence (cung zad yod), and are only concepts (rtog pa tsam) that are empty of any intrinsic nature (rang bzhin gis stong)." (ŚSK 42) ${ }^{16}$

Another defence of this claim comes from Candrakīti's commentary on Nāgārjuna's Yuktișaștikārikā (YṢK 34). ${ }^{17}$ There Candrakīrti argues that all determinate categories, sensory faculties, and phenomenological experiences are dependent on our conceptual constructs, and these in turn depend on the conventional terminologies of everyday language. Candrakīrti's argument, then, is that cognitions apprehend the objects of experience, and those objects that we experienced are conceptually (therefore linguistically) represented in the cognitions

\footnotetext{
12 Dbu ma tsa 25b: ji ltar bcom ldan de bzhin gshegs, ,rdzu 'phrul gyis ni sprul pa sprul, ,sprul pa de yis slar yang ni, ,sprul pa gzhan zhig sprul gyur pa, ,de la de bzhin gshegs sprul stong, ,sprul pas sprul pa smos ci dgos, ,gnyis po ming tsam yod pa yang, ,gang ci'ang rung ste rtog pa tsam, ,

13 There are two Indian commentaries for this text preserved in the Tibetan, one is by Nāgārjuna himself Śñnayatāsaptativrtti (Dbu ma tsa 110a-121a), as clearly attributed to Nāgārjna, which ends with these words (Dbu ma tsa 121a): tong pa nyid bdun cu pa'i bshad pa, slob dpon 'phags pa klu sgrub kyis mdzad pa rdzogs so,, ,, The second is attributed to Candrakīti (Dbu ma ya 267a-336b) as the end reads (Dbu ma ya 336b): stong nyid bdun cu pa'i rgya cher 'grel pa slob dpon zla ba grags pas mdzad,, pa rdzogs so,, ,,

14 There is a slight terminological variation between Nāgārjuna's ŚSK 41 which reads: "Whatever they may become" (gang ci'ang rung te), and Candrakīrti's commentary ŚSV 41. It is possible, although, Candrakīti could be using a different version of the root text when he was writing the commentary.

15 Dbu ma ya 319a: Gnyis po'i ming tsam yod pa yang, ,gang cung zad de rtog pa tsam zhes bya ba snying po dang bral ba ste rang bzhin dang bral ba zhes bya ba'i don to, ,

${ }^{16}$ Dbu ma tsa 25b: de bzhin byed po sprul dang mtsungs, ,las ni sprul pas sprul dang mtsungs, ,rang bzhin gyis stong gang cung zad, ,yod pa de dag rtog pa tzam, ,

17 Dbu ma Tsa 21b: 'byung ba che la sogs bshad pa, ,rnam par shes su yang dag 'du, ,de shes pas ni 'bral 'gyur na, ,log par rnam brtags ma yin nam, Skt text (ed.) Kumar (1993) mahābhūtādaya khyātā vijñāne nicayastathā | tajjūānena viyukttena mrșaiva na vikalpitam $\| 34$
} 
as having the representations of some specific categories. When a reality Q could not be represented as any form whatsoever in any cognition, it is not possible for the mundane convention to linguistically posit $\mathrm{Q}$ as really existing. Therefore all of the known phenomena (that we can claim to have knowledge of, from the primary elements and the derivatives of the primary elements, to minds and mental factors, as well as physical entities not associated with the minds) are determined by our conceptual linguistic activities, understood within the framework of these cognitive processes, and hence have to be regarded as conceptually categorised entities (YȘK 34). ${ }^{18}$

The semantic realists may object here stating that if realities are mere concepts, how could they be said to exist? For this Candrakīrti replies that the existence of entities are evidenced from them being apprehended ${ }^{19}$ to exist nominally, as linguistic entities, as mere concepts (rtog pa tsam). Whereas those entities that are nonexistents (the Pegasus, the Unicorn etc.) are not apprehended to exist even nominally.

So, what follows from this premise is that the existence (reality) of all entities exhaust (yongs su) in merely being designated (brtags pa tsam). "They are unreal (yang dag par ma yin pa) for they are empty of any intrinsic reality, but are merely conceptually fabricated (sgro btags pa tsam): falsely (brdzun pa) and deceptively (bslu)" "20 - for despite the linguistic character of the entities, they do indeed appear to non-analytical cognitive process to be intrinsically non-linguistic entities possessing objective reality.

The Prāsangika's semantic theory is fundamentally different from the semantic realism of Theravāda, Vaibhāṣika, Sautrāntika (even Svātantrika) all of which argue that language and reality are mutually exclusive, and that linguistic concepts apply only to the unreality-conventional truths. Vaibhāṣika argues that language

\footnotetext{
18 Dbu ma ya 21b-22a:'byung ba che la sogs bshad pa, ,rnam par shes su yang dag 'du, ,de shes pas ni 'bral 'gyur na, ,log par rnam [22a], ,brtags ma yin nam, ,zhes bya ba smos so, ,rnam par shes pas dmigs pa gang gi rnam pa 'dzin cing skye ba'i dmigs pa de, rnam par shes pa la rnam pa nye bar bsgrubs pa'i rang gi dngos po

thob nas dngos po'i don gyi ngo bo nyid kyis 'byung ba chen po la sogs par yongs su brtags so, ,rnam par shes pa la 'ga' zhig gi rnam par ma bzhag pa la ni 'jig rten gyis yod pa nyid du rnam par gzhag mi nus te, mo gsham gyi bu la sogs pa yang yod par thal bar 'gyur ba'i phyir ro, ,de bas na 'byung ba dang 'byung ba las gyur pa dang, sems dang sems las byung ba dang, sems dang ldan pa ma yin pa rnams ni rnam par shes pa'i rnam pa'i rgyu can

yin pa'i phyir 'byung ba chen po la sogs pa gang dang gang bshad pa ci yang rung ba de dag thams cad ni rnam par shes par yang dag par 'du zhing khongs su chud do, ,

19 Dbu ma ya 319a: Gang 'dir yang dag pa'i de bzhin gshegs pas sprul pa'i sprul pa de nyid re zhig stong pa ste de bzhin gshegs pa'i rang bzhin dang bral ba'o, ,ci 'on te gang sprul pa'i sprul pa the tsom med par 'di ni de bzhin gshegs pa'i rang bzhin dang bral ba yin gyi,sprul pa'di yang rnam pa thams cad kyis med do zhes brjod par mi nus te, de dag nye bar dmigs bzhin pa'i phyir ro zhes gsungs pa,

${ }^{20}$ Dbu ma ya 319a: Slar yang ji ltar de yod ce na, gsungs pa rtogs pa tsam zhes bya ba la yongs su brtags pa tsam yang dag pa ma yin par sgro btags pa tsam brdzun pa slu ba'i chos can tsam zhes bya ba'i don to,
} 
expresses and applies strictly to conventional truth. ${ }^{21}$ It maintians conventional truth (samvrtisatya), composite-existence (avayavi-dravya / rdzas grub), and the lack of intrinsic nature (nihsvabhāva) are all equivalents. Therefore Vaibhāșika maintains that language applies to three types of things which are reducible, derived and constructed. Concepts that disintegrate when subjected to physical destruction and disappear from our minds when their parts are separated in logical analysis, are thus reducible physically and logically. Those concepts that borrow their identity from other things including their parts and properties that lack the intrinsic nature (nihsvabhāva) required for independent existence, are derived properties. Those concepts that are product of mental constructions apply to the aggregations of appearance of inherence. Such mental constructions include wholes, causation, and temporal continuum etc., they are thus constructed.

On Sautrāntika's view the divide between language and reality is even sharper. Dharmakīrti opens his chapter on perception (Pratyakșa) in Verses on Rightcognition (Pramānavārttikakārikāa), by arguing that there are two type of objects one of which is the domain of language the one that is ultimately causally inefficient), and the other is not the domain of language the one that is ultimately causally efficient. Linguistic entities are strict domains of inferential cognition (pramānas) and non-linguistic entities are strict domains of perceptual cognition. ${ }^{22}$ The non-linguistic objects are the ultimate existents (paramārthasat) which are defined as ultimately causally efficient, and they constitute the unique particulars (svalakșana). The linguistic entities are the conventional existents (samvrtisat) which are defined as ultimately causally inefficient, and they constitute the universals (sāmānyalakșaṇa). ${ }^{23}$

\footnotetext{
${ }^{21}$ Conventional truth consists of reducible spatial wholes or temporal continua. In the Abhidharmakośa Vasubandu defines conventional truth / reality as follows: "An entity, the cognition of which does not arise when it is destroyed and, mentally divided, is conventionally existent like a pot and water. Ultimate existence is otherwise." (AbhiDK 6.4) (Mngon pa khu 7ab): Gang la bcom dang blo yis gzhan // [7b] bsal na de blo mi 'jug pa // bum chu bzhin du kun rdzob tu // yod de... Vasubandhu's autocommentary, the Abhidharmakośabhāşya, explains the verse as follows: "Something conventionally exists if the cognition of it does not arise upon its division into parts, like a pot. There is no cognition of a pot when it is broken into pieces. And something conventionally exists if the concept of it does not arise when its properties are mentally stripped away, like water. The cognition of water does not arise when properties such as shape and the like have been excluded from it by the mind. And it is on the basis of these (components) that the conventional designations are formed. Thus the statement 'pot and water exist' is true, through the power of convention. It is not false; it is conventional truth." (AbhiDKB 6.4) (Mngon pa khu 7b): gang la cha shas su bcom na de'i blo mi 'jug pa de ni kun rdzob tu yod pa ste / dper na bum pa lta bu'o / de la ni gyo mor bcom na bum pa'i blo mi 'jug go // gang la blos chos gzhan bsal na de’i blo mi 'jug pa de yang kun rdzob tu yod pa yin par khong du chud par bya ste / dper na chu lta bu'o / de la ni blos gzugs la sogs pa'i chos bsal na chu'i blo mi 'jug go // de dag kho na la kun rdzob tu de'i ming du ba tags pa yin pas kun rdzob kyi dbang gis bum pa dang chu yod do zhes brjod pa ni bden pa kho na smras pa yin gyi / brdzun pa ni ma yin pas de ni kun rdzob kyi bden pa yin no //

22 PVK 2.1-2.2., Tshad ma ce 118b: Gzhal bya gnyis phyir tshad ma gnyis // don byed nus dang mi nus phyir // skra shad la sogs don min te // don du mos pa med phyir ro // 'dra dang mi 'dra nyid phyir dang // sgra yi yul dang yul min phyir // rgyu mtshan gzhan ni yod pa na // blo ni yod dang med phyir ro //

23 Dharmakīrti PVK Tshad ma ce 118b: Arthkryāsamartham yat tadatra paramārthasat / Añyata sam̃vtisat prokatạn te svasāmānyalakșañe /2.3/ Don dam don byed nus pa gang // de 'dir don dam yod pa yin // gzhan ni kun rdzob yod pa ste / de dag rang spyi'i mtshan nyid bshad // In the Álamanaparīkșa Dignāga (Tshad ma ce 92a) applies the concept of causal efficiency to define right-cognition (pramāna) don byed nus pa'i dngos su gzhal ba'i phyir te tsad ma'ang yin no // This same idea Dharmakīti uses in
} 
Dharmakīti confines language and concepts within the domain of conventional truth as dharma that is 'conventionally existent' and he identifies conventional truth with the "universal" (sāmannya-lakșana $)^{24}$ just as he identifies ultimate truth with the unique particular. ${ }^{25}$ Universal is a conceptual entity not apprehended by virtue of its own being or unique reality - a general property that is conceptually constructed, and appears to be common to objects of a certain class. The Sautrāntika view of universals as conceptual constructs stands in stark contrast to the Nyāya-Vaiśeșika view of them as objectively real and eternal entities that inhere in the substances, qualities and particulars that bear them. Sautrāntika hold a view known as nominalism or conceptualism - a view denying universals any extra-mental reality.

The Sautrāntika defends the claim that the universals (sāmānya-lakșaṇa) are only conventional truths on the following five grounds (tshad ma ce 118b). First, they argue that universals are the domains of inferential cognition since they are exhaustively grasped by the conceptual mind by the means of language and thought. ${ }^{26}$ While unique particulars exist independently of linguistic convention, universals have no reality absent linguistic and conceptual conventions. Universals are therefore only conventionally real, lacking any intrinsic nature. Unique particulars, on the other hand, are ultimately real, and exist intrinsically.

Second, they argue that universals are objects whose apprehension is a cognition mired in intuitive beliefs about the objects rather than a cognition that demands that its object withstands critical analysis. This is related to the first argument. Since universals are constructed conceptually and linguistically, they ought also to be deconstructed in kind. Our failure to do so by subjecting them to critical analysis, the Sautrāntika argues, disguises their constructed-ness and confines our belief in them as they are to the realm of intuition.

Third, they argue that universals are causally inefficient. As we have seen, for Sautrāntikas, a condition of reality is causal efficiency. To be causally efficient is to produce an effect at a particular time. The production of an effect requires a transformation of the producer, under the power of requisite conditions. An entity incapable of change would therefore also be incapable of producing a effect at any time.

Fourth, universals are products of the conceptual thought intruding where it ought not. They are constructed by assimilation of thought and language with referential objects (unique particulars) that are by nature independent from them, and thus rendering in our mind what is by nature ineffably complex as simple, discrete as unified, parts as whole.

Footnote 23 continued

PVK to define right-cognition (Tshad ma ce 107b): tshad ma bslu med can shes pa // don byed nus par gnas pa ni // mi slu sgra las byung ba yang // mngon par 'dod pa ston phyir ro /1.1/

24 The term sāmānya-lakṣaṇa has been variously translated as "generally characterised," "generally defined," and "universal", or "generality."

25 Dharmakīrti PVV Tshad ma ce 118b: Gzhan ni kun rdzob yod pa ste / de dag rang spyi 'i mtshan nyid bshad //

${ }^{26}$ Dharmakīrti, Nyāyabindu, tshad ma ce 231a: Anyat sāmānyalakșaṇam / so 'numānasys viṣayah / gzhan ni spyi’i mtsan nyid de / de ni rjes su dpag pa'i yul yin no /) 
Finally, and as a consequence of the previous points, universals, obscure the individualities of the unique particulars from being directly apprehended. This is because, as we have already seen, universals, according to Dharmakirti's $\mathrm{PVK}^{27}$ and PVT, ${ }^{28}$ are conceptually constructed from cognitively fusing the distinct individualities of the unique particulars. The critical point is the conceptual mind is ignorant of its constructive role and treats its creation as uncreated-the perception of a natural property rather than the superposition of concept. As a result, the conceptual mind obscures us from seeing directly the component individual characteristics to which the concept has been applied.

On the Yogācāra account the contradistinction between language and reality is also very clearly drawn. Reality is nondual-freedom of any conceptualitylanguage is equally divorced from any ground of reality. The wedge between language and reality is drawn with its two truths theory. The Yogācāra asserts that conventional reality is but the ideas, images, and creations of the mind, outside of which no corresponding object exists. The external physical universe is a mentally constructed universe. All physical objects are fictions, unreal even conventionally, and are similar to dreams or mirages in which all we seem to outwardly perceive have been inwardly produced. The claim that only mind is real is the focus of the Yogācāra treatises ${ }^{29}$ including Vasubandhu's fundamental treatise, the Vimśatika (Vim Sems tsam shi 3a-4a). In it, Vasubandhu states: "All this is indeed only consciousness, because of the appearance in it of nonexisting objects just like the

\footnotetext{
27 Tshad ma ce 97ab: Tha dad dngos rnams la brten nas // don gcig tu ni snang ba'i blo // gang gi rang gi ngo bo yis // gzhan gyi ngo bo sgrib byed pa // sgrib byed des bdag tha dad kyang // tha dad pa nyid bsgribs pa yis // dngos rnams ngo bo 'ga' zhig gis // tha dad min pa lta bur snang // 'de la bsam pa'i dbang gis na // spyi yod [97b] par ni rab tu bsgrags // de yis ji ltar kun brtags pa // de ni dam pa'i don du med // 28 Tshad ma ce 282a: Rnam par rtog pa can gyi blo ni de dag las gzhan pa las ldog pa can gyi dngos po rnams la brten nas skye ba na / rang [282b] gi bag chags kyi rang bzhin byed cing de dag gi ngo bo tha dad pa mi snang bar byas nas / bdag nyid kyi rnam pa tha dad pa med pa zhen par byas te / de rnams 'dres par kun du ston to // bsgrub par bya ba dang / sgrub pa gcig pa can nyid kyis na gzhan las tha dad pa' $i$ dngos po rnams dang / rnam par rtog pa de'i bag chags kyi rang bzhin na de dag las skye ba can 'di de lta bur snang ba gang yin pa de yin no // da ni kun rdzob ste 'dis rang gi ngo bos gzhan gyi ngo bo sgrib pa' $i$ phyir ro // de dag ni des tha dad pa bsgribs pas bdag nyid kyis tha dad kyang ngo bo 'ga' zhig gis tha mi dad pa bzhin du snang ngo // de bas na rjes su byed pa rnams kyi blo'i snang ba la blo la snang ba'i dngos po la rnam pa'i khyad par yongs su 'dzin pas phyi rol lta bur kun tu 'phro ba de dag kho na'i spyi yin bar brjod do //

29 Now many of the the Yogācāra texts are available in English translations. Stefan Anacker, in his Seven Works of Vasubandhu: The Buddhist Psychological Doctor (2002), produced the translations of six seminal works of Vasubandhu on Yogācāra: A Discussion on the five Aggregates (Pañcaskandhaka Prakarana), A Discussion For the Demonstration of Action (Karma Siddhi Prakarana), The Twenty Verses (Vimśatikā kārikā [vṛtti]), The Thirty Verses (Trimśikā kārikā), Commentary on the Separation of the Middle From Extremes (Madhyānta Vibhāga Bhāśya), and The Discernment of the Three Natures (Tri Svabhāva Niṛdeśa). Fernando Tola and Carman Dragonett's Being as Consciousness: Yogācara Philosophy of Buddhism, (Delhi: Motilal Banarsidass Publishers, 2004), offers us excellent studies of the Yogācāra philosophy in addition to the translations of Dignāga's Investigation About the Support of the Cognition (Ālambanaparīkșāvrtti), Vasubandhu's The Twenty Stanzas: The Demonstration of the Only Existence of Consciousness (Vimśatikā vijñaptimātratāsiddhiḥ), and Kārikās on the Three Natures (Trisvabhāvakārikā). Swati Ganguly's Treatise in Thirty Verses on Mere Consciousness (1992) provides a critical English translation of Hsün-tsang's Chinese Version of the Vijñaptimātratātrimśikā with notes from Dharmapāla's commentary in Chinese. Jay Garfield's Empty Words: Buddhist Philosophy and Cross-Cultural Interpretation (2002) has in it a study of the three natures and three naturelessness, a translation and commentary on Vasubandu's Treatise on the Three Natures (Tri Svabhāva Nirdeśa).
} 
vision of the nonexistent net of hairs, moons etc., by someone afflicted with an optical illusion." (Sems tsam shi 3a) ${ }^{30}$

Yogācāra's claims that anything that is linguistic and conceptual are entirely unreal. The external objects are entirely unreal, and that only mental objects may be conventionally real is bound up in the Yogācāra theory of the three natures (trisvabhāva). In his Trisvabhāvakārikāa, or Trisvabhāvanirdeśa (TSN) Vasubandhu explains the Yogācāra ontology and phenomenology as consisting of the unity of three natures (svabhāva): (1) the dependent or other (paratantra); (2) the imaginary / conceptual (parikalpita); and (3) the perfect / ultimate (parinispanna). ${ }^{31}$ The first two account for conventional truth and the latter ultimate truth. Language and concepts are applicable only to the first two and they constitutes conventional truth and the third which is the nondual reality must be, by definition, entirely non-linguistic and nonceptual. Therefore the Yogācāra argues that conventional truth is rooted in three forms of convention: fabrication (asatkalpita), consciousness (vijñāna), and a linguistic signifier (śabda). Respectively, a conventional truth is fabricated by the conceptual mind, apprehended in error by the dualistic consciousness, and invested with meaning by its signifier. The Yogācāra treat the products of the three conventions as separate categories of conventional truth: the truths of fabrication, consciousness and language. Truths of fabrication and language are labelled conceptual nature (parikalpita) whilst truths of consciousness are labelled dependent nature (paratantra).

What is clear from this is that all semantic realists agree that reality and language are divorced from each other: wherever linguistic concepts are application there reality is not, and wherever reality is applicable there linguistic concepts are not applicable. For the Prāsangika however, reality and language operate at the same level and domain.

\section{Nirvāṇa and Ultimate Truth are Concepts}

What about nirvāṇa or ultimate truth? Could it be argued that they exist as merely names or concepts? The Buddhist semantic realists' answer to this question is one of an unequivocal negative. They hold the view that ultimate truth (by extension nirvānaa) is ineffable: non-conceptual and extra-linguistic. The linguistic concepts and ultimate truth can never coincide - the two are mutually exclusive.

Vaibhāșika for example argues since language is strict domain of three intertwined qualities of: reducibility, derivation and construction that determine what is social conventional. Reality (ultimate truth) is completely and totally free from any linguistic and conceptual convention. Because ultimate reality is defined

\footnotetext{
30 Vijñaptimātramevaitadasadarthāvabhāsanāt / yathā taimirikasyāsatkeśacandrādidarśanam // Vk_1 // ('di dag rnam par rig tsam nyid // yod pa ma yin don snang phyir // dper na rab rib can dag gis // skra zla la sogs med mthong bzhin //1//)

31 TSN 1, Sems tsam shi 10a: Kalpitah paratantraśca pariniṣpanna eva ca / trayah svabhāvā dhīrānām gambhīrajñeyamisyate // 1 // brtags dang gzhan gyi dbang dang ni // yongs su grub pa nyid dag ste // rang bzhin gsum po brtan rnams kyi // zab mo yi ni shes byar 'dod //1//
} 
as irreducible and independent it is linguistically unconstructed. ${ }^{32}$ It is not the product of linguistic constructions. Its intrinsic nature exists independently of all concepts, including the conceptual mind. This, Vaibhāșika says is for two reasons. First, ultimate reality is irreducible as it is immune to physical destruction and resists the logical analysis that would otherwise undermine its identity by separating it from its parts. Second, it is independent in the sense it does not borrow its unique reality (svalakșana) from elsewhere, including from its parts. It exists simply in virtue of its intrinsic nature (svabhāva).

For the Vaibhāṣika, there are two types of ultimates: the uncompounded ultimate (asamskrta), and compounded ultimate (samskrta). The uncompounded ultimate consists of (a) space (akāśa), and (b) nirvāna, which they further sub-divide into analytical cessation (pratisamkyā-nirodha) and non-analytical cessation (apratisamkhya-nirodha). They are 'uncompounded' because they are immune to reduction. They resist physical reduction because they are non-spatial concepts devoid of the slightest physical referent. The Vaibhāșika treats them as immune to logical reduction too, because in their ontological estimation, they are not subjected to causal conditioning. Since anything composite or compounded is vulnerable to physical or analytical deconstruction, anything that resists such deconstruction does so because it is primary and 'uncompounded'.

Vaibhāṣika treats the uncompounded trio (space and the two forms of cessation) as non-linguistic and ultimately real on the ground that they are foundational entities. ${ }^{33}$ As we have seen, the trio are foundational entities because they are (i) independent entities, although composite in nature, (ii) unconditioned entities as they are not causally produced, (iii) intrinsically real, (iv) objective domains of cognitions, (v) eternal entities that endure through time, and (vi) indissoluble entities the cognitions of which continue to arise even after their parts are mentally stripped away.

\footnotetext{
32 The Sarvāstivādins' definition of the ultimate truth is precisely the opposite of their definition of conventional truth. Vasubandu writes: "Ultimate truth ... is ultimate existence, e.g., material form (rūpa), the concept of which survives its destruction and the mental exclusion of other properties. Even when form [aggregate] is divided up into atoms, and even when the mind takes away from it properties such as taste and the like, there is still the concept of the intrinsic nature (svabhāva) of form. Feeling etc. must be seen in the same way. Because this exists ultimately, it is known as ultimate truth." (AbhiDKB, Mngon pa khu 214a): De las gzhan pa ni don dam pa'i bden pa ste / gang la bcom yang de’i blo 'jug pa kho na yin la / blos chos gzhan bsal yang de'i blo 'jug pa de ni don dam par yod pa yin te / dper na gzugs lta bu'o / de la rdul phra bar tu bcom yang rung / blos ro la sogs pa'i chos bsal kyang rung gzugs kyi rang bzhin gyi blo 'jug pa nyid de / tsor ba la sogs pa yang de bzhin du blta bar bya'o // de ni don dam par yod pa'i phyir don dam pa'i bden pa zhes bya'o /

33 ADKB Mngon pa ku 94a: Reg bya med pa tsam ni nam mkha' yin te / 'di ltar mun pa'i nang dag na thogs pa ma rnyed na nam mkha'o zhes zer to / phra rgyas dang skye ba skyes pa 'gags nas so sor brtags pa'i stobs kyis gzhan mi skye ba ni so sor brtags pas 'gog pa yin no // so sor brtags pa med pa kho nar rkyen ma tshang bas mi skye ba ni so sor brtags pa ma yin pas 'gog pa ste dper na bar ma dor 'chi ba'i ris mthun pa lhag ma lta bu'o zhes zer ro // Yang bral ba zhes bya ba 'di ci / sngar so sor brtags pas 'gog pa yin no zhes ma bshad dam / de'i tshe ni so sor brtags pas 'gog pa gang zhe na / gang bral ba'o zhes bshad / da ni bral ba gang zhe na / gang so sor brtags pas 'gog pa'o zhes bshad pas phan tshun rten pa'i bshad pa 'di ni de'i rang gi ngo bo gsal bar bya ba la nus pa ma yin te / de lta bas na de'i rang gi ngo bo gzhan du brjod par bya'o // de'i rang gi ngo bo ni 'phags pa rnams kho nas so sor rang gis rig par bya ba yin te / bral ba zhes bya ba dang / so sor brtags pa'i 'gog pa zhes bya ba gang yin pa brtags pa dang dge ba'i rdzas gzhan zhig yod do zhes bya ba de tsam zhig ni brjod par nus so //
} 
The Sautrāntika, on the other hand, treat the trio as only conventionally real on the grounds that they are conceptual entities, and mere negative phenomena. ${ }^{34}$ Space, it agues, is merely the absence of any obstructive property or point of contact. Analytic cessation is just the cessation of the afflictions and their dispositions - a cessation brought about by the wisdom of the analytic mind. Nonanalytic cessation refers to the absence of the afflictions, not because of their elimination by the analytic mind, but simply because they lack the conditions necessary for them to arise.

By implication, what is ultimately true for Vaibhāșika is something whose existence does not at all depend on the power of concepts and convention. For the Vaibhāșika, such a thing is "foundationally existent" (dravya-sat / rdzas yod). ${ }^{35} \mathrm{We}$ have seen that to apply singular concepts to "compositely existent" (avayavidravya / rdzas grub) requires the intervening glue of concept. For "foundationally existent" things, though, that glue is totally unnecessary, since such things are as simple and irreducible as the concepts that refer to them. In the case of something foundationally existent there always remains something irreducible to which the concept of the thing applies. Foundationally existent things are ultimately real since they are true irrespective of convention.

For Sautrāntika "unique particulars ${ }^{36}$ share the characteristics of ultimate truths previously mentioned (they are irreducible, independent and unconstructed) as well as two further characteristics. They serve as the objects of direct perception, and present themselves to that perception as distinctive / unique. As Dharmakīti says:

\footnotetext{
${ }^{34}$ ADKB Mngon pa ku 94a: Mdo sde pa rnams na re 'dus ma byas thams cad kyang rdzas su med pa kho na ste / de ni gzugs dang tsor pa la sogs pa bzhin du rdzas gzhan du ni med do / 'o na ci zhe na / reg bya med pa tsam ni nam mkha' yin te / 'di ltar mun pa'i nang dag na thogs pa ma rnyed na nam mkha'o zhes zer to / phra rgyas dang skye ba skyes pa 'gags nas so sor brtags pa'i stobs kyis gzhan mi skye ba ni so sor brtags pas 'gog pa yin no / so sor brtags pa med pa kho nar rkyen ma tshang bas mi skye ba ni so sor brtags pa ma yin pas 'gog pa ste dper na bar ma dor 'chi ba'i ris mthun pa lhag ma lta bu'o zhes zer ro // ${ }^{35}$ Dravya is also a central concept in the Nyāya-Vaiśeșika tradition. There is a fundamental distinction to be drawn between dravya as a "foundational entity" in the Sarvāstivāda and dravya as "substance" in the Nyāya-Vaiśeșika tradition. According to the Nyāya-Vaiśeșika all objects of experience come under seven categories: (i) substance (dravya), (ii) quality (guṇa), (iii) action (karma), (iv) universal (sāmānya), (v) particular (viśeșa), (vi) inherence (samavāya), and (vii) nonexistence (abhāva). The most fundamental of the categories is undoubtedly substance (dravya). Substance denotes the objective reality of things, it exists in and of itself, is self-subsistent. Substance is the substrate of qualities and actions (present or potential) either in the relation of intimate union (samavāya-sambandha) or the future existence, antecedent negation (prāgabhāva). Substance is divided into two general categories: eternal and noneternal substances. Substance that depends on something else is non-eternal, hence composite substances (avayavidravya) are dependent and impermanent. The eternal substances are simple, independent and unique. Eternal substances are neither caused nor destroyed, whereas non-eternal substance are caused and destroyed, not by themselves, but by the force of something other than them. Substance is of nine kinds: earth (prithivi), water (up) fire, tejas), air (vāyu), ether (ākāśa), time (kāla), space (dik), self (ātman), and mind (manas). The nine substances are all eternal and infinitesimal, they form the basis for compound (avayavidravya) and destructible substances.

${ }^{36}$ All unique particulars are themselves universals (samānyalakșana), i.e., they are comprised of generality, class concepts or characteristics that are instantiated by their own unique particulars bearing the conceptual constructions. The universal is not an object of perceptual cognition. Rather it is only the unique particular that is presented to a right-perceptual cognition appearing to it as though it has intrinsic reality, it appears to the cognitions with its unique individualities, thus does not appear to the cognition as being conceptually constructed.
} 
"because things intrinsically exist uniquely, and as distinct entities, there is differentiation between similar and dissimilar things." 37

Unique particulars are not denotable by language since they are beyond the full grasp of any conceptual mind (śabdasyāviśaya). Although unique particulars are the objective referents of language and thought, language and thought can only refer to them approximately, indirectly. While beliefs about them may be formed, to the extent that those beliefs are the product of a conceptual mind, and language (which is by nature conceptual), to that extent they are flawed and incomplete, hence conceptual mind does not and cannot fully grasp and express their real nature.

Unique particulars or the ultimate truths are instead directly cognisable by a certain perception free from cognitive defects and independent of language and thought. For the Sautrāntika-logician such an epistemically correct perception is the arbiter of unique particulars, and benchmark for ultimate reality. Thus, if a perception is correct and warrants cognitive authority (pramāna) about its objects, it also qualifies that object as a unique particular. Since this type of perception is considered authoritative, to be perceived by it, is considered proof of its ultimate status.

In the Sautāntika ontology, such a perception reveals unique particulars of three kinds: (i) momentary instants of matter (rüpa), (ii) momentary instants of consciousness (vijñāna) and (iii) momentary instants of the non-associated composite phenomena, which are neither matter nor minds or mental factors (citta-caitta-viprayukta-samskāra).

The Sautrāntika's theory of ultimate truth mirrors its ontology of flux in which unique particulars are viewed as infinitesimal atoms constituting momentary events (kșanika) or as successive flashes of consciousnesses constituting cognitive events. In either case, they are processes devoid of substrata. Even the continuity of things and motion is an illusion-rather than the endurance of something substantive, it is simply an ephemeral process in which successive events resemble each other.

Unique particulars are ultimately real, but do not and cannot endure. Rather, they are bundles of events which arise and disappear instantly because they are selfdestructive, existential and motionless.

In short, the "determinate intrinsic natures of the unique particulars are not accidental or fortuitous since ... (they are) spatially, temporally and ontologically determinate." 38 For something to present itself as unique or distinctive, Dharmakīrti argues that it must satisfy at least three criteria: ${ }^{39}$ Real things are determinate in time and space, and determined precisely and constantly by their causal conditions.

\footnotetext{
37 Dharmakīrti PVK Tshad ma ce 96a: Sarve bhāvāh svabhāvena svasvabhāvayavasthiteh / svabhāvaparabhāvābhyām yasmād vyāvṛttibhāgināh //

Gang phyir dngos kun rang bzhin gyis // rang rang ngo bo la gnas phyir // mthun dngos gzhan gyi dngos dag las // ldog pa la ni brten pa can //

38 Dharmakīrti PVT Tshad ma ce 179a: Don rnams kyi rang bzhin nges pa yang glo bur bar ni mi rigs te / ltos pa med pa ni yul dang dus dang rdzas nges par mi 'thad pa''i phyir ro //

39 Dharmakīrti PVT Tshad ma ce 274b: Dngos po thams cad ni rang gi ngo bo la gnas pa can kho na yin no // de dag ni rang dang gzhan du 'dre bar mi byed de // de gzhan ma yin pa nyid du thal bar "gyur ro // gang yang 'di dag gi rang bdag nyid du gyur pa'i ngo bo tha mi dad pa de ni de dag gi ma yin te / de'i tse de dag med pa'i phyir ro // de kho na yin par 'gyur te / tha mi dad pa yin pa'i phyir dang / de las ma gtogs pa tha dad pa yang med pa'i phyir ro // de nyid tha dad par ni 'gal ba'i phyir ro // de yang bdag nyid la
} 
Although unique particulars are determined, language and thought have no role in that determination. Accordingly, since they are apart from the things' identity, they can refer to that identity only approximately. As Dharmakīrti puts it, "[language] does not denote the real things since all things exist by virtue of their own identities. The stripy identity does not exist in the golden identity. At the same time excluding the individual identities, there is nothing else in both that exists." 40 Apart from the individual conditions, there is no substance or property existing over and above them that unifies the individuality of the unique particulars. The identity of a stripy cow for example, says Dharmakīrti, is a cow produced by the particular causal conditions having the specific causal capacities. It is not due to "cowness" as the property it shares with white or striped cows contrary to the Nyāya-Vaiśeșika assertation. ${ }^{41}$ For the Sautrāntika, there is no such thing as a property of "cowness" distinct from being black or white cows. The distinctive ontological status of all the unique particulars, has in them their real causal conditions, as factors clearly individuating them from other real things.

The Prāsangika maintains that both nirvāṇa and ultimate truth are linguistic concepts and argues that they exist as merely names or concepts. Hence it answers "Yes" to the above question. Consider this passage from Candrakīrti's Yuktișaștikāvṛtti:

Footnote 39 continued

rnam par gnas pas ma 'dres pa kho na yin no // don gzhan yang du ma dang 'brel du zin kyang de ni de dag gi spyi ma yin te / de'i ngo bo ma yin pa'i phyir ro // gnyis nyid la sogs pa dang ldan pa dang / 'bras bu'i rdzas dag la yang thal bar 'gyur ba'i phyir ro // 'brel pa can gzhan gyis kyang gzhan dag mtsungs pa ni ma yin gyi de dang ldan pa dag tu ni 'gyur te /'byung po' i mgul chings lta bu'o // shes pa tha mi dad pa' $i$ yul yang ma yin te / 'byung po bzhin no // blo ni de dag gi bdag nyid kho na bsre zhing spyi $i$ yul can du snang gi gcig dang 'brel ba can dag go zhes bya ba ni ma yin te /'byung po lta bu'oll Also see Dharmakīti PVT Tshad ma ce $279 \mathrm{~b}$.

40 Dharmakīrti Tshad ma ce 100a: Dngos po la min dngos po kun // rang rang ngo bo la gnas phyir // khra bo yi ni ngo bo gang // de ni ser skya la yod min // de 'bras yin min las bzlog pa // gnyis ka la yang yod pa min // don la tha dad med par yang // sgra yi tha dad mi rigs so // de phyir de 'bras 'dod na yang // de 'bras med las tha dad nyid // dper na mig la sogs pas gzugs // rnam shes gcig gi 'bras bu can // gang phyir khyad par med 'bras de // ston pa dag ni srid par 'gyur // 'ga' zhig cig car kun rtogs phyir // de yi ngo bo spyi las ni // tha dad med du zin na yang // brda las byung ba snyad par bya // gal te gcig gnas pa yi phyir // mang po dag la 'ang mnyan pa gcig // gnas pa rten nam gsal ba yin // de ltar de la mi rigs so //

41 The Vaiśeșikas believes in a very different concept of the universals. They claim that universal is the common or generalised characteristic essential to all objects belonging to any particular class. The Vaiśeșika argues that we can explain the nature of phenomena either in their particular distinct characteristics or their kinds or general characteristics. It identifies objects as "particulars" by virtue of their distinctness and identifies objects as "universals" by virtue of their similarity. For the Vaiśeșikas the universal is eternal (nityam), one (ekam) and residing in many (anekānugatam) things belonging to the same group of substance, quality, or action. It inheres in all things of the same genus / class (svavișayasarvagatam), with an identical nature (abhinnātmakam) and is the cause of the notion of concordance (anuvrttipratyayakāranam) (Vaiśeșika-sūtra v.2.4, 7-10) Substance, quality and action have residing in them the universals whereas it does not inher in the universal, particular, inherence and nonexistence. Universal cannot exist in another universal. Treeness (vṛkṣattva) and potness (ghațatva) are themselves universals, and cannot have another one common to all of them as it would lead to an infinite regress. Just as particulars have objective existence so have the universals and thus both are equally real. Universals are not just class-concepts but class-essence, the sameness that breathes through similar particular objects. Substance (dravya) refers to all the substances whereas the substanceness (dravyatva) is common to all the substances, thus it is a universal. Likewise quality (guna) refers to individual qualities and qualityness (gunatva) is common to all qualities, hence a universal. 
It is just so! Since samsāra is also a concept (rtog), nirvāṇa too must be a concept (rtog pa), for they both exist as mundane linguistic conventions (loka-vyvahāra / 'jig rten gyi tha snyad). For this reason it is proclaimed in the Prajñāpāramitā-sūtra as follows: [Śāriputra]: "Venerable Subhūti, do you claim that even nirvāṇa is like an illusion, like a dream?" [Subhūti replies]: Śāriputra, even if there were a truth that surpasses nirvāṇa, I would still say, 'This is like an illusion.' If nirvāṇa were not dependent upon the conception of saṃsāra, it would not be like an illusion. Since [it is dependent, however], even nirvāna is to be conceptualised (rtogs pa) as a conventional truth. (YṢV $5 \mathrm{~cd})^{42}$

In the defence of the thesis that ultimate truth and nirvāna are linguistic concepts, here Candrakīrti supplies us two arguments: (i) that both are mundane linguistic conventions (loka-vyvahāra / 'jig rten gyi tha snyad), hence conventional truths, and (ii) that both are linguistically and conceptually dependent upon each other, hence illusion-like and dream-like.

Here the semantic realists could mount a challenge to the Prāsangika's position as being inconsistent with the Buddha's teachings. They could object that nirvāna is not a linguistic concept (but it is the meaning or referent to which concept and language refer), and therefore not a conventional truth, for the Buddha himself had stated that: "Nirvāṇa is the ultimate truth." In fact Nāgārjuna himself has stated:

"Nirvāṇa is the only truth," is what the Victors declared. Then, what wise person would suppose "Everything else is not false. (YṢK 35) ${ }^{43}$

There are three ways in which the Prāsangika could respond to this objection. First, it could say that is not inconsistent with the Buddha's teaching to maintain that the nirvāna and ultimate truth are concepts. The Buddha's statement "Nirvāna is the ultimate truth" is only a linguistic statement, since it is a linguistic utterance based on the linguistic convention, understood, and made sense, only within the bound of linguistic conventions. Nirvāna is a "conventional truth" in this sense-it is no different from any other linguistically constructed concepts. The statement neither explicitly nor implicitly points towards the existence of any ultimately real meaning which the semantic realist wants to insinuate.

Second, the Buddha's statement "Nirvāna is the ultimate truth" is conventionally meaningful statement in several ways. Nirvāna is a convenient designator for the

\footnotetext{
${ }^{42}$ Dbu ma ya 7b: ci mya ngan las 'das pa yang kun rdzob kyi bden pa yin nam, de de bzhin te, 'khor bar yongs su rtog pa yod na mya ngan las 'das par yongs su rtog ste, de gnyi ga yang 'jig rten gyi tha snyad yin pa'I phyir ro, ,de bas na bcom ldan 'das ma las gsungs pa, tshe dang ldan pa rab 'byor mya ngan las 'das pa yang sgyu ma lta bu rmi lam lta bu'o zhes smra'am, sh'a ri'i bu mya ngan las 'das pa bas ches lhag pa'i chos shig yod na yang sgyu ma lta bu'o zhes kho bo smra'o zhes 'byung ngo, gal te de 'khor bar rtog pa la ltos pa ma yin na de sgyu ma lta bur mi 'gyur ro, ,de bas na mya ngan las 'das pa yang kun rdzob kyi bden par yongs su brtags pa yin no, ,

43 Dbu ma Tsa 21b: mya ngan 'das pa bden gcig pur, ,rgyal ba rnams kyis gang gsungs pa, ,de tse lhag ma log min zhes, ,mkhas pa su zhig rtog par byed, ,
} 
cessation of, or the ultimate freedom from the suffering and the origin of suffering. This is in contrast with the "conventional truths" of other three truths-suffering, origin and path. The conventional truth, while causally produced, unreal, insubstantial, and impermanent, it deceptively appears to the cognitive processes to be unproduced, substantial, real and permanent. By contrast the ultimate truth (nirvāna) is a non-produced-mere freedom from the suffering and the origin —and it presents to the cognitive process just the way it really is, non-deceptively. Nirvāna is not like a produced phenomenon that deceives the ordinary beings with false appearances. Since it retains its non-arising nature consistently (rtag tu), it does not appear to the ordinary beings as produced things do, they appear deceptively.

Thus, through mundane linguistic convention ('jig rten gyi tha snyad kyis) "nirvāṇa is expressed (bshad) as 'ultimate truth' (paramārtha-satya / don dam bden pa) for it always is a transcendent of suffering." (YȘK 5cd) ${ }^{44}$ Candrakīrti therefore insists, nirvāna is the ultimate truth, in a conventional sense, but not in the sense of expressing any underlying ultimate meaning or referent.

Candrakīti brings out the above first two arguments together as follows:

[i] It is called 'ultimate truth' (paramārtha-satya / don dam bden pa) by means of the mundane linguistic convention (loka-vyvahāra / 'jig rten gyi tha snyad), [ii] for its nature is non-deceptive with respect to the world. Anything that is produced is deceptive, and it is not ultimate truth. [The other] three [noble] truths are therefore presented as conventional truths, since they are characteristically produced, and they do appear to be intrinsically real (ngo bo nyid yod par snang ba) and thus they deceive the ordinary beings. (YSSV $5 \mathrm{~cd}$ ) ${ }^{45}$

The third reason is that the Prāsangika maintians it is a category mistake to assume that there exists ontological / metaphysical dichotomy between nirvāṇa and samsāra or between ultimate truth and conventional truth. On this point Candrakīrti again follows Nāgārjuna who has said:

Those who do not see reality assume the [duality of] samiāa and nirvāṇa. Those who do see reality as it is do not assume either samsāra and nirvāna. $\left(\right.$ YȘK 5ab) ${ }^{46}$

\footnotetext{
${ }_{44}$ Dbu ma ya 7b-8a: 'o na bcom ldan 'das kyis dge slong dag 'di lta ste, mi slu ba'i chos can mya ngan las 'das pa 'di ni bden pa'i mchog gcig pu'o zhes gsungs pa de ji lta bu, ji ltar 'dus byas log par snang bas byis pa rnams la slu ba de bzhin du mya ngan [8a], ,las 'das pa ni de lta ma yin te, rtag par skye ba med pa'i rang gi ngo bor gnas pa'i phyir de ni byis pa rnams la 'dus byas ltar skye ba'i ngo bor nam yang mi snang ngo, ,de bas na mya ngan las 'das pa ni rtag tu mya ngan las 'das pa nyid du gnas pas 'jig rten gyi tha snyad kyis don dam pa'i bden pa zhes bshad do,

45 Dbu ma ya 7b: gal te de ltar na mya ngan las 'das pa don dam pa'i bden pa'o zhes ji skad du bshad, de'i bdag nyid du 'jig rten la mi slu ba'i phyir 'jig rten gyi tha snyad kyis don dam pa'i bden pa zhes bshad do, , slu ba 'dus byas gang yin pa de ni don dam pa'i bden pa ma yin no, ,bden pa gsum ni 'dus byas kyi mtshan nyid de ngo bo nyid yod par snang bas byis pa rnams la slu ba'i phyir kun rdzob kyi bden par rnam par gzhag go, ,

${ }^{46}$ Dbu ma Tsa 20b: de nyid ma mthong 'jig rten dang, ,mya ngan 'das par rlom sems te, ,de nyid gzigs rnams 'jig rten dang, ,mya ngan 'das par rlom sems med, , Skt. Preserved in Āryadeva's Cittaviśuddhiprakaraṇa (cited in Lindtner, Nāgājuniana, ? 104): saṁāaram caiva nirvānam manyante 'tattvadarśinah / na samsāram na nirvāṇam manyante tattvadarśinaḥ //
} 
Commenting on this passage, Candrakīrti argues that only those who lacked insight into the reality stresses on the radical duality of samsāra and nirvāna - they are the ones who objectify samsāra as the intrinsic disease to be abandoned (mi mthun pa'i phyogs) and nirvāna as the intrinsic cure that needs to be cultivated (gnyen po'i dgnos po). Exalted beings who have the realisation of reality as it is however do not objectify the intrinsic reality of neither samsāra nor nirvāna, they neither construct nor perceive the ontological dichotomy between the two. Therefore, both samsāra and nirvāna exist as concepts only on the strength of the conceptual construction of the naïve individuals (byis pa'i skye bu). Thus the claim that samsāra and nirvāna exists as ontological being (dngos po) and ontological non-being (dngos med) does not reflect a proper understanding of the Prāsangika. ${ }^{47}$

In the Samyuttanikāya I.20, the Buddha explains how ultimate awakening involves recognition of that the conventional truth is process of conceptual designation and consequent understanding of the ultimate truth involves recognition of person's lack of ultimately real self:

Those who go by names, who go by concepts... are subject to the reign of death; he who has discerned the naming-process does not suppose that one who names exists. No such case exists for him in truth, whereby one could say: "He's this or that." 48

At this point another objection can be mounted against the Prāsangika's semantic theory. The semantic realists could charge the Prāsangika's semantic theory of failing to recognise the distinction between unreal concepts (such as rabbit's horn, the Pegasus, the Unicorn etc.) from real concepts (the form, feeling, perception etc.). According to the semantic realists, if all entities or things are concepts, it does not leave any benchmark to differentiat between what is real from the unreal.

This is an important objection that the Prāsangika needs to address. The response from the Prāsangika, briefly goes something like this. It maintains an important distinction between the two statements: "All realites are linguistic concepts" and "All linguistic concepts are realities." The objection raised is premised on the

\footnotetext{
${ }^{47}$ Dbu ma Ya 7a: yang dag mthong bas 'jig rten dang, ,mya ngan 'das par rlom sems med, ,'phags pa ngo bo nyid mi dmigs pa'i chos rtogs pas rab tu phye ba rnams ni de gnyi ga mi dmigs shing mi rtog go zhes bya bar dgongs so, de bas na byis pa'i skye bo'i rtog pa'i dbang du 'khor ba dang mya ngan las 'das pa gnyis yod do zhes bstan pas dngos po dang dngos po med pa gnyis yod do zhes gang smras pa de rigs pa ma yin no, This distinction, fallacious though it may be from the Prāsangika point of view (for it falsely objectifies both samisāra and nirvāna), is said to be pedagogically uself. The distinction generates an aspiration in the minds of the ordinary beings to overcome their false objectifications of the samsāric entities. This eventually leads them to abandon the tendency to falsely objectify and cling to the concept of nirvāna. (YṢV 5ab) Sde b 'ka' Dbu ma ya 6b-7a: yang dag ma mthong 'jig rten dang, ,mya ngan 'das par rlom sems te, , zhes smos so, ,de kho na mi mthong ba ni 'khor ba zhes brjod pa, 'jig rten [7a], ,dang de ldog pa zhes brjod pa mya ngan las 'das pa 'di gnyis la mi mthun pa'i phyogs dang gnyen po'i dngos por gnas shing gcig ni blang gcig ni dor bar sems, ,de de'i phyir te skye bo 'khor ba la rgyab kyis lta bar 'gyur zhing de ldog pa la mos pa skyes pa dag la rten cing 'brel par 'byung ba bstan pas spang bar bya ba'i skye ba med pa bde bar rtogs par nus so, , dngos po skye ba med par rtogs na dngos po med pa la ci zhig gi dngos po med pa mya ngan las 'das par brtag ces mya ngan las 'das pa la mngon bar chags pa yang bde bar spong nus so, ,de ltar de kho na nyid mthong la zhugs nas 'phags par gyur pa de ni,,

48 Samyuttanikāya 1.20, trans. Maurice Walshe in Samyutta Nikāya: An Anthology (Kandy, Sri Lanka: Buddhist Publication Society, 1985).
} 
assumption that the implications of these two statements are the same: it assumes that the latter thesis is entailed in the former-namely, to say that "All realites are linguistic concepts" is, for the objector, equal to saying that: "All linguistic concepts are realities." For the Prāsangika these two statements reflect two different implications and commitments. The Prāsangika is committed to the former but not to the latter and it argues that the latter is not entailed in the former.

\section{Not All Linguistic Expressions (Concepts and Names) are Realities}

Although, as I have shown in the previous section, that for the Prāsangika reality or existence (yod pa) amounts to be merely (tsam) nominal (ming), symbolic (brda), and therefore linguistic (tha snyad), but it does not follow from this thesis that the Prāsangika has to hold the view that says whatever is postulated by the 'linguistic cognitive framework (tha snyad 'dogs pa'i blo) ${ }^{49}$ has to be accepted as real. That is true even though it does hold the view that reality could not be something that is not postulated by the linguistic cognitive framework. ${ }^{50}$ As Tsongkhapa explains:

By 'merely nominal' (ming tsam) we mean that reality is not discoverable through any analysis into the meaning (of the objective referent) of the linguistic convention. And this [1] does not mean that [only] names exist while categories do not (ming yod cing don med pa'am), [2] nor does it mean that there is nothing which is not name (ming ma yin pa'i do med pa ma yin). ${ }^{51}$

So the Prāsangika's key thesis is this: not every linguistic postulates (tha snyad 'dogs pa'i blo) ${ }^{52}$ amounts to posting reality, even though there is no reality that is not linguistic postulates. ${ }^{53}$ Candrakirti's key argument is that we cannot conceive of any reality whatsoever that could be singled out or identified as a non-linguistic, for we cannot think and talk about anything that we can claim to have knowledge of without that thing being conceptually and linguistically represented in our cognitive processes. Therefore there cannot be anything that is not a product of the framework of linguistic cognitive process.

From the Prāsangika's own standpoint, there is no such thing as true or real mundane concepts. The mundane linguistic concepts used by the ordinary beings are necessarily false because those concepts necessary operate on the assumption of

\footnotetext{
49 Thurman (1984, p. 296) translates this phrase as "verbally ascriptive conventional intellect."

50 Tsongkhapa, Gsung 'bum 67b-68a, DNLS (1997, pp. 199-202) 'dir ming gi tha snyad 'dogs pa'i blos gang gzhag thams cad tha snyad du yod par mi bzhed kyang tha snyad 'dogs pa'i blo'i dbang [68a], ,gis ma bzhag pa'i tha snyad du yod pa mi bzhed do, ,

51 Tsongkhapa, Gsung 'bum 67b, DNLS (1997, pp. 199-201-2) thal'gyur bas ni ... yod pa rnams kyang ming dang brda dang tha snyad tsam du lan mang por bshad pa'i phyir ro, ,ming tsam gyi don ni sngar ltar tha snyad kyi Don btsal ba na mi rnyed pa la byed kyi ming yod cing don med pa'am ming ma yin pa'i don med pa ni ma yin no, ,

52 Thurman (1984, p. 296) translates this phrase as "verbally ascriptive conventional intellect."

53 Tsongkhapa, Gsung 'bum 67b-68a, DNLS (1997: 199-202) 'dir ming gi tha snyad 'dogs pa'i blos gang gzhag thams cad tha snyad du yod par mi bzhed kyang tha snyad 'dogs pa'i blo'i dbang [68a], ,gis ma bzhag pa'i tha snyad du yod pa mi bzhed do, ,
} 
object's intrinsic nature, they objectify the objects that they apprehend. However, the Prāsangika adopts the mundane practice in which classifies linguistic concepts into two types: (1) conventionally true concepts and (2) conventionally false concepts. Conventionally true concepts constitute conventional truth and conventionally false concepts are excluded from the categories of conventional truth, such concepts are described as non-mundane. The sky-flower, the horns of rabbit, the hairs of tortoise, the son of a barren women etc., are names on the bases of which we are able to form concepts, but they are false concepts produced by the frameworks of defective linguistic cognitive processes. Candrakīrti explains:

The objects grasped by all six mundane sense faculties, if these sense faculties are not impaired by the causes of defects ... are true only in relation to the mundane cognitive processes but not from the perspective of the noble beings. Those objects - such as reflections-that appear objectively true (yul gyi ngo bo), only when the sense faculties are impaired by the causes of defects, are false / unreal by the standard of mundane cognitive processes. ${ }^{54}$

Concepts associated with the sense faculties that are unimpaired by the extraneous causes of misconception correctly represent the (conventional) truth of their objects (hence the objects so represented are classed as conventionally true), and because these types of conceptual representations are able to fulfil the realistic mundane epistemic and linguistic standards, they are defined as true-concepts by the mundane convention.

The concepts associated with the sense faculties that are impaired by the extraneous causes of misperception misrepresent the conventional truth of their object (hence those objects so misrepresented are classed as conventionally false), and because these type of conceptual misrepresentations fail to meet the realistic mundane epistemic and linguistic standard, such concepts are classed as falseconcepts.

Putting the distinction differently: true concepts determine the definition of "conventional truth" (lokasamvrtisatya / jig rten kun brdzob bden pa) based on reliable cognitive processes. Their representations postulate and frame the mundane conventions (i.e., healthy sense faculties) and set its standard. False-concepts, on the other hand, determine the definition of "non-conventional truth" (alokasamvritisatya) 'jig rten ma yin pa'i kun brdzob bden pa) based on the fabrications of the nonmundane conventions (alokasamvrti / jig rten ma yin pa'i kun rdzob) of the unreliable cognitive processes. Since the representations of these concepts are false even by the mundane standard, and they are thus excluded from the categories of mundane conventional truths / realities.

\footnotetext{
54 MBh 6.25 Dbu ma 'a 254a: De'i phyir de ltar 'jig rten gyis dbang po la gnod pa'i rkyen ji skad du bshad pa med par dbang po drug car gyis gzung bar bya ba'i don rtogs pa de ni jig rten nyid las bden pa yin gyi 'phags pa la ltos nas ni ma yin no // gzugs brnyan la sogs pa gang zhig dbang po rnams la gnod pa yod pa na yul gyi ngo bo nyid du snang ba de ni 'jig rten nyid la ltos nas log pa yin no // Cf. "Those objects that are apprehended by the unimpaired sense faculties are the ones mundane cognitive processes perceive. They are real from the perspective of the mundane cognitive processes. All the rest is said to be unreal." (M 6.25 Dbu ma 'a 205a): Gnod pa med pa'i dbang po drug rnams kyis // gzung ba gang zhig 'jig rten gyis rtogs te // jig rten nyid las bden yin lhag ma ni // "jig rten nyid las log par rnam par bzhag //
} 
The convention of correct conceptual process is associated with an acute sense faculty, which is not impaired by any occasional extraneous causes ${ }^{55}$ of misconception. This form of conception is identified as mundane convention (lokasamvrti / 'jig rten gyi kun rdzob). The convention of fallacious conceptual process is associated with a defective sense faculty impaired by occasional extraneous causes of misconception such as vision blurredness ( $r a b$ rib), cataract (ling thog sngon po), jaundice (mig ser) etc. This form of fallacious conceptual process is identified as "non-mundane convention" (alokasamvrti / "jig rten ma yin pa'i kun rdzob).

Therefore the distinction between mundane and non-mundane concepts rests on whether or not the cognitive processes in question are defected by the presence of the extraneous causes of misconceptions. Those that are defected by the extraneous causes are excluded from the mundane convention, hence classified as non-mundane convention.

\section{Linguistic Concepts are Causally Effective}

We shall consider one final objection against the Prāsangika's semantic theory before we wind up the discussion: If reality is just linguistic concepts, and since linguistic concepts are utterly empty of intrinsic nature, how could such reality have any functional or causal efficacy. Recall the famous objection advanced by the Naiyāyika against Nāgārjuna's philosophy of language which appears in the opening verse of the Vigrahavyāvartanīkārika (VVK) and Vigrahavyāvartanīvrtti (VVV).

If an intrinsic nature (svabhāva) of the entities (bhāva), whatever they may be, exists nowhere (sarvatra na vidyate), your [very] statement must be empty of

\footnotetext{
55 Included in these extraneous causes, among other things, are three types of temporary causes: (i) The internal causes of defects of the sense faculties are such as cataracts, jaundice and the consumption of hallucinogenic substances. ( $M B h 6.25 \mathrm{Dbu} \mathrm{ma}$ 'a 253b): De la rab rib dang mig ser la sogs pa dag dang da dur zos pa la sogs pa rnams ni dbang po la gnod pa'i rkyan nang na yod pa yin no // (ii) The external causes of defects of the sense faculties include water, mirrors, the echoing of sound in caves, and the rays of the sun falling in specific location at particular time, movement etc. These external causes can respectively produce, even without presence of the internal defects of the sense faculties, misperception of a reflection as real object, the image as face, the echo as sound, the mirage as water, sends the objects in motion when one is in a movement. Magical tricks also causes illusion such as animals to appear real etc. (MBh 6.25 Dbu ma 'a 253b-254a): Til mar dang chu dang me long dang brag phug la sogs pa nas brjod pa'i sgra la sogs pa rnams dang / nyi ma'i 'od zer yul dang dus khyad par can dang nye bar gyur pa la sogs pa rnams ni dbang po [254a] la gnod pa'i rkyen phyi rol na yod pa yin te / de dag ni dbang po la gnod par byed pa nang na yod pa dag med par / gzugs brnyan dang brag ca dang smig rgyu la chu la sogs par 'dzin pa'i rgyur 'gyur ro // de bzhin du mig 'khrul mkhan la sogs par rab tu sbyar ba'i sngags dang sman la sogs pa dag kyang shes par bya'o / (iii) The causes of the defects of the mental faculty are, in addition to the above causes, erroneous philosophical beliefs, fallacious inferences, and sleep. (MBh 6.25 Dbu ma 'a 254a): Yid kyi gnod par byed pa ni de dag dang yang dag pa ma yin pas byas pa'i grub pa'i mtha' la sogs pa dag dang / rjes su dpag pa ltar snang bdag ste / rmi lam la sogs pa rnams kyi rnam par gzhag pa ni 'chad par 'gyur ro //
} 
an intrinsic nature (asvabhāva). It is not therefore, in a position to deny the intrinsic nature [of the entities]. (VV.1) ${ }^{56}$

In the Vigrahavyāvartan̄ Nāgārjuna considers in a good detail the Naiyāyika's objections against his position from the first to the twentienth verses. The commentary explains the thrust of the objection as follows. Because linguistic concepts are empty of intrinsic nature, all the statements are also empty of intrinsic nature. Since whatever is empty of intrinsic nature equals to nonexistent, and since whatever is nonexistent cannot perform any function, linguistic concepts that are empty of intrinsic nature would not perform the practical functions of the language such as representing objects, making the statements about the truths, or even the function of denying intrinsic reality of language. ${ }^{57}$ According to the Naiyāyika opponent, "just as a fire that does not exist cannot burn, a weapon that does not exist cannot cut, water that does not exist cannot moisten; a statement that does not exist cannot deny the intrinsic nature of all things." 58

The Naiyāyika's objection nicely captures the semantic realism's view including some of the Buddhist view on the nature of language and its meaning or functional efficiency. The objection enables us to understand the opponent's implicit assumptions. According to the semantic theory of Nyāya as long as one accepts language as meaningful and functionally efficient, one must also attribute intrinsic nature (svabhāva) to language without which, it maintains, language is nonexistent, therefore cannot function and express any meaning. As long as language's intrinsic nature is denied, one must also reject linguistic meaning and its functional efficiency. Since the Prāsangika rejects language's intrinsic nature, it must also reject any linguistic meaning. Therefore it concludes that language that is empty of intrinsic nature has no practical use.

The bone of contention is the ontology of intrinsic nature whether the debate is between the Prāsañgika and Naiyāyika's that features in Vigrahavyāvartan̄̄ and that of the current amongst the semantic realism of Buddhist_-Vaibhāṣika, Sautrāntika, Yogācāra—and the semantic non-realism of the Prāsangika. The Naiyāyika claims

\footnotetext{
56 See Nāgārjuna's Vigrahavyāvartanīkārika/vrtti (VV.1): sarveșām bhāvānām sarvatra na vidyate

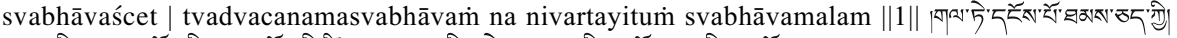

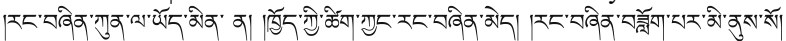

57 Because the statement is neither in its causes (the four great elements (mahābūta), taken collectively or severally (samprayukteșu viprayukteșu vā) nor in its conditions (the efforts made in the breast, the throat, the lips, the tongue, the roots of the teeth, the palate, the nose, the head etc.) nor in the combination of both the causes and the conditions, nor again is it anyingthing apart from the causes and the conditions. Since it is nowhere, it is empty of an intrinsic nature and since it is empty of intrinsic nature,

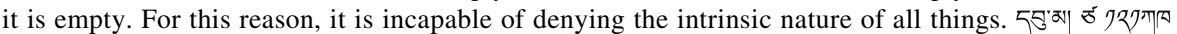

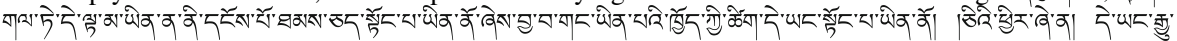

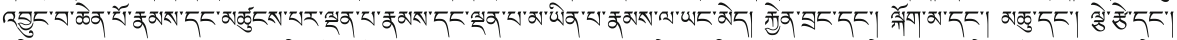

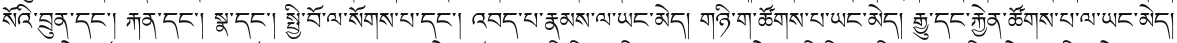

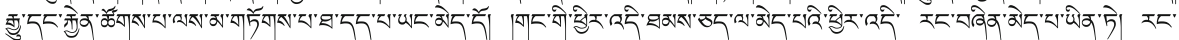

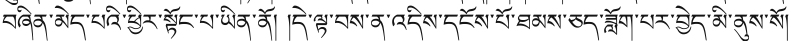

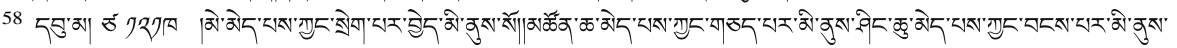

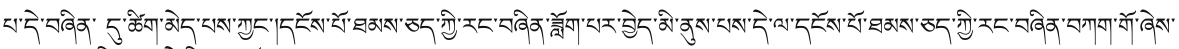

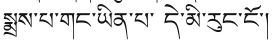


that causal efficiency of language must be tied down together with its intrinsic nature, and the Prāsangika's rejection of intrinsic nature must therefore be seen as rejecting the causal efficiency of language itself. Buddhist semantic realism similarly maintains that the causal efficiency of reality is tied together with its intrinsic nature, and since the Prāsangika rejects intrinsic reality and asserts that reality is simply linguistic concepts empty of any intrinsic nature, such rejection is therefore to be concluded as rejecting the causal efficiency of reality.

Since the bone of contention is the same the Prāsangika response to the Naiyāyika and the Buddhist realists' objection is the same. From the verse twenty first to seventy the Vigrahavyāvartani systematically respond to those objections. We shall appropriate the thrust of Nāgārjuna's argument in establishing the causal efficiency of linguistic concepts or the non-intrinsic reality.

Language is empty of intrinsic nature because they exist neither in its causes, taken collectively or separately (samprayukteșu viprayukteșu vā), nor in its conditions, nor in the combination of both (the cause and the conditions), nor again is language anything apart from the causes and the conditions. Since the linguistic concepts are no where to be found intrinsically, language is empty of intrinsic nature. Even so the empty statement effectively establishes the emptiness of the things because the things themselves are empty of an intrinsic nature. (VV.21) ${ }^{59}$

Emptiness is that nature of things which is dependently originated (pratityasamutpannatvāt). The words are dependently originated from the causes and conditions because they arise from the four great elements (mahābhūta) —earth, water, fire, air etc. as the causes (hetu) - and the intentional efforts to make utterances made in the breast, the throat, the lips, the tongue, the roots of teeth, the palate, the nose, the head etc., as the conditions (prtyayasapekșatvāt). This is Nāgārjuna says similar to things like a cart, a pot, a cloth, etc., though empty of an intrinsic reality (svabhāvaśūnya) because of being dependently arisen, are occupied with their respective functions, e.g., a cart for carrying wood, grass and earth, a pot for containing honey, water and milk, and a cloth for protecting from cold, wind and heat. (VVV.22) ${ }^{60}$ In the Catuhśatakațīka, Candrakīrti employs the same argument: "when vases etc., are analysed critically in five ways, they do not exist either separately from or identical to their causes. Nevertheless, through being

\footnotetext{
59 Vaidya, P. L. (ed.) hetupratyayasāmagryām pṛthagbhāve'pi madvaco na yadi| nanu

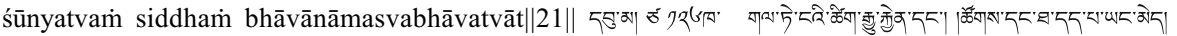

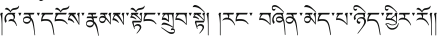

${ }^{60}$ Nāgārjuna (2005,p. 107): Yathā ca pratītyasamutpannatvāt svabhāvaśūnyā api rathapaṭaghațādayaḥ sveșu sveșu kāryeșu kāṣthaṛthrnamṛttikārhaṇe madhūdakapayasām dhāraṇe sítavātāoaoarutrānaprabhṛtiṣu vartante / 22 /

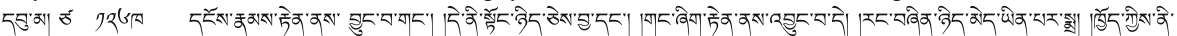

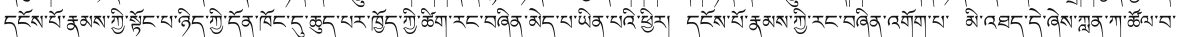

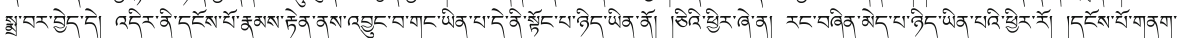

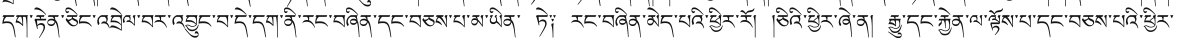

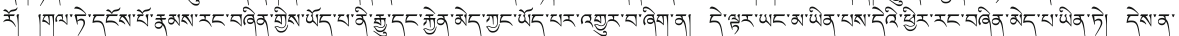

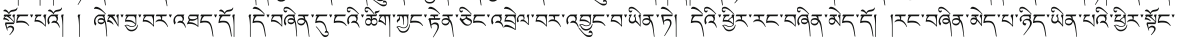

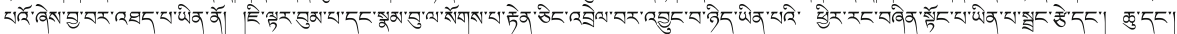

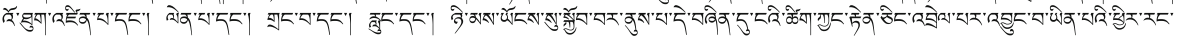

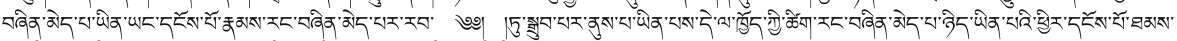

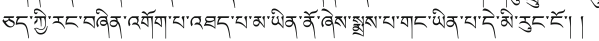


dependently designated (brten nas btags pas) they are able hold honey, water, milk, and they function to scoops water etc." (CŚT ?) ${ }^{61}$ Language functions and it is causally effective precisely on the ground that it is empty of any intrinsic nature and therefore dependently originated.

Suppose that a magician artificially creates two illusory persons (māyāprușa): illusory person ${ }_{1}$ and illusory person ${ }_{2}$. It is possible that one illusory man can destroy the other illusory man despite that both persons are illusory. Or that one illusory person can prevent the other illusory person from occupying certain space. There the illusory person who does the act of preventing is empty of intrinsic nature, so too, is the person who is being prevented from occupying the space. Similarly a negation of things' intrinsic nature is possible by language even though itself is intrinsically empty (śūnyenāpi). Therefore Naiyāyika's refutation that because of the emptiness of the language, a negation of intrinsic reality of things is not feasible by means of such language, is not valid. (VVV.23) ${ }^{62}$

Candrakīti's Madhyamakāvatāra / bhāśya argues that the argument of the sevenfold reasoning reinforces the idea that the linguistic concept "self" is meaningful only in the domain of convention. The conventional self constitutes being dependently and conceptually designated on the five aggregates in as much as a chariot is dependently designated on its parts. ( $M / M B h$ 6.158) Just as a concept "chariot" is no more than a convenient designator in dependence on its parts such as wheels, axel etc., without the need of any intrinsic chariot to be found anywhere in the parts, taken collectively or individually, and yet it is known in the world as "agent" that performs its function. Even so, the linguistic concept "self" is no more established than a dependent designator on the five aggregates without having the need of any intrinsic self to be found anywhere in the aggregates, taken collectively or individually, and yet non-inttrinsic self concept serves as a moral agency in the conventional self. Therefore, the denial of intrinsic reality does not ential the denial of nominal concept. It only goes to show the existence of the latter. (M/MBh 6.159).

So, all forms of linguistic concepts are convenient designators taken for granted, non-analytically, in the everyday purpose.

\section{Conclusion}

The semanatic realists theorise that reality must be unique and intrinsic, and without the quality of intrinsic and uniqueness, reality could not be causally ineffective. The Prāsangika's semantic theory however argues that if reality is unique (svalakșaṇa) and intrinsic (svabhāva) it would have no functional efficiency whatsoever.

\footnotetext{
${ }^{61}$ Dbu ma Ya 207a: bum pa la sogs pa rnams rang gi rgyu las de nyid dang gzhan du rnam pa lngar dpyad pa na yod pa ma yin mod kyi; de lta na yang brten nas brtags pas sbrang rtzi dang chu dang 'o ma 'dzin pa dang 'chu ba la sogs pa'i bya ba la rung bar 'gyur ba 'di ci ngo mtsar ba zhig gam,

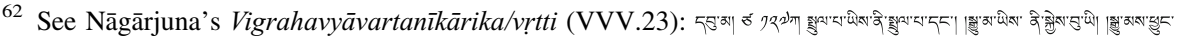

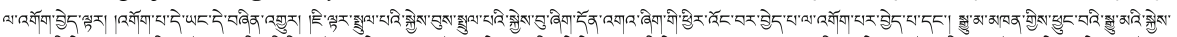

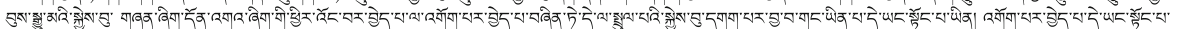

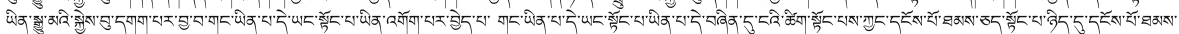

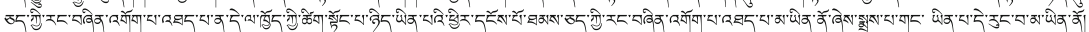


Therefore the Prāsangika argues reality is linguistic concepts with no intrinsic nature whatsover and the reality is so only nominally and it is intrinsically empty. In defending this semantic theory, I considered several arguments which have been advanced in the works of Nāgārjuna, Candrakīrti and Tsongkhapa.

First, it has been argued that all conventional realities (including all entities) are linguistic concepts, for they constitute entities that are conceptually represented in the minds via mundane linguistic expressions. Second, ultimate truth and nirvāṇa are demonstrated to be linguistic concepts because they are also concepts that arose dependently with respect "conventional truth" and "samsāra" respectively. Moreover ultimate truth and nirvāṇa are not ontologically transcendent of conventional and samsāra, rather ultimate truth is the understanding of the conventional truth as a mere concept; and nirvāna is the understanding of samsāra as a mere concept. Third and the final argument discussed in the paper is in direct response to the semantic realism's charge that the semantic nominalism thesis of the Prāsangika would fail to address the practical needs of linguistic functions. Here it is argued that the Prāsangika's nominalism thesis is not susceptible to such nihilistic charge, for it can plausibly explain the causal efficacy of linguistic concepts based on the principles of dependent designation. Therefore the arguments I have considered here collectively demonstrate that language and reality are already mutually embedded within one another-language is constitutively embedded in the mundane truths, so too are truths constitutively embedded in linguistic representations.

The Prāsangika's account does not ential the denial of reality and linguistic function, and that its semantic theory does not undermine the linguistic convention and its application. The Prāsangika show cases the natural correlation between the emptiness of language and its causal efficiency and demonstratively shows that the only language empty of intrinsic nature can performs linguistic functions and not the non-empty language.

\section{References}

Anacker, S. (2002). Seven works of Vasubandhu: The Buddhist Psychological Doctor. Delhi: Motilal Banarsidass Publishers Private Limited.

Āryadeva. (1998). Four hundred verses (Catuhśatakakārikā CŚK tsha 1b-18a). Sde dge edition of the Bstan 'gyur. Dharmasala: Paljor Press.

Ātiśa. (1998). Introduction on The Two Truths (Satyadvāyāvatāra SDA, Dbu ma a 72a-73a). Sde dge edition of the Bstan 'gyur. Dharmasala: Paljor Press.

Buddhapālita. (1998). Buddhapālitamūlamadhyamakavrttti. (Dbu ma tsa 158b-281a). Sde dge edition of the Bstan 'gyur. Dharmasala: Paljor Press.

Candrakīrti. (1960). Madhyamakaśāstravṛtti. In P. L. Vaidya (Ed.), Madhyamakaśāstra of Nāgārjuna with the commentary: Prasannapadā by Candrakīti. Darbhanga: The Mithila Institute of Post-Graduate Studies and Research in Sanskrit Learning.

Candrakīrti. (1998). Commentary on the Seventy Verses on Emptiness (Ś́̄nayatāsaptativrtti ŚSV, Dbu ma tsa 110a-121a). Sde dge edition of the Bstan 'gyur. Dharmasala: Paljor Press.

Candrakīrti. (1998). Clear-word commentary on the fundamental verses of the middle way (Mülamadhyamakavrttiprasannapadā MMKVPP. Dbu ma 'a 1b-200a). Sde dge edition of the Bstan 'gyur. Dharmasala: Paljor Press.

Candrakīrti. (1998). An introduction on Madhyamaka (Madhyamakāvatāra MA. Dbu ma 'a 201b-219a). Sde dge edition of the Bstan 'gyur. Dharmasala: Paljor Press. 
Candrakīrti. (1998). Commentary on the introduction on Madhyamaka (Madhyamakāvatārabhāśya MAB. Dbu ma 'a 220b-348a). Sde dge edition of the Bstan 'gyur. Dharmasala: Paljor Press.

Candrakīti. (1998). Commentary on the four hundred verses (Catuhśatakațika CŚT, Dbu ma ya 30b239a). Sde dge edition of the Bstan 'gyur. Dharmasala: Paljor Press.

Candrakīrti. (1998). Commentary on the seventy verses on emptiness (Śūnayatāsaptativrtti ŚSV, Dbu ma ya 267a-336b). Sde dge edition of the Bstan 'gyur. Dharmasala: Paljor Press.

Candrakīrti. (1998). Commentary on the sixty verses on reasoning (Yuktișașțikavrtii YȘV Dbu ma ya 1b-30b). Sde dge edition of the Bstan 'gyur. Dharmasala: Paljor Press.

Candrakīrti. (1998). Discussion on the five aggregates (Pañcaskandhaprakarana PSP. Dbu ma ya 239b266b). Sde dge edition of the Bstan 'gyur. Dharmasala: Paljor Press.

Changkya Rölpai Dorje (Lcang skya Rol pa'i rdo rje). (1989). Ornament of the philosophical systems (Grub mtha' thug bstan lhun po'i mdes rgyan. Xiling: Mtsho sngon mi rigs par khang.

Ganguly, S. (1992). Treatise in thirty verses on mere consciousness. Delhi: Motilal Banarsidass Publishers Private Limited.

Garfield, J. (2002). Empty words: Buddhist philosophy and cross-cultural interpretation. Oxford: Oxford University Press.

Nāgārjuna. (1998a). Fundamental verses of the middle way (Mūlamadhyamakakārikā MKK Dbu ma tsa 1b-19a). Sde dge edition of the Bstan 'gyur. Dharmasala: Paljor Press.

Nāgārjuna. (1998b). Sixty verses on reasoning (Yuktișașthikākārikā, YȘK. Dbu ma tsa 20b-22b). Sde dge edition of the Bstan 'gyur. Dharmasala: Paljor Press.

Nāgārjuna. (1998c). Vaidalyasūtra (VS Dbu ma sa 22b-24a). Sde dge edition of the Bstan 'gyur. Dharmasala: Paljor Press.

Nāgārjuna. (1998d). Seventy Verses on Emptiness (Śūnyatāsaptatikārikā, ŚSK. Dbu ma tsa 24a-27a). Sde dge edition of the Bstan 'gyur. Dharmasala: Paljor Press.

Nāgārjuna. (1998e). Verses Rebutting the Disputes (Vigrahavyāvartan̄̄kārikā, VVK. Dbu ma Tsa 27a29a). Sde dge edition of the Bstan 'gyur. Dharmasala: Paljor Press.

Nāgārjuna. (1998f). Commentary on the Verse Rebutting the Disputes (Vigrahavyāvartanīvrtti, VVV. Dbu ma Tsa 121a-137a). Sde dge edition of the Bstan 'gyur. Dharmasala: Paljor Press.

Nāgārjuna. (1998g). Jewel Lamp of the Middle Way (Madhyamakaratnapradīpa).

Śāntideva. (1998). Engaging in Bodhisattva's conduct (Bodhicāryāvatāra BCA Dbu ma la 1b-40a). Sde dge edition of the Bstan 'gyur. Dharmasala: Paljor Press.

Thurman, R. A. F. (1984). The Speech of Gold: Reason and Enlightenment in the Tibetan Buddhism. Delhi: Motilal Banarsidass.

Tsongkhapa Lobsang Dakpa (Tsongkhapa Blo bzang Grags pa). (1970). Eight difficult points in the fundamental wisdom of the middle way (Rtsa ba shes rab kyi dka' gnas chen po brgyad kyi bshad pa). Sarnath: Pleasure of Elegant Sayings Press.

Tsongkhapa Lobsang Dakpa (Tsongkhapa Blo bzang Grags pa). (1984b). Illumination of the middle way thought (Dbu ma dgongs pa rab gsal). Sarnath: Gelukpa Students' Welfare Committee.

Tsongkhapa Lobsang Dakpa (Tsongkhapa Blo bzang Grags pa). (1985). Verses on the three principal paths (Lam gtso rnam gsum gyi rtsa ba). In the dbu ma'i lta khrid phyogs bsdebs. Sarnath: Gelukpa Students' Welfare Committee.

Tsongkhapa Lobsang Dakpa (Tsongkhapa Blo bzang Grags pa). (1992). Ocean of reasoning (Rtsa shes țk chen rigs pa'i mgrya mtsho). Sarnath: Gelukpa Students' Welfare Committee.

Tsongkhapa Lobsang Dakpa (Tsongkhapa Blo bzang Grags pa). (1993). Great stages of the path (Byang chub lam gyi rim pa chen mo LRCM). Sarnath: Gelukpa Students' Welfare Committee.

Tsongkhapa Lobsang Dakpa (Tsongkhapa Blo bzang Grags pa). (1994a). Essential eulogy of the dependent arising (Rten 'brel stod pa legs bshad snying po). In Ācārya Gyaltsen Namdol \& Ācārya Ngawang Samten (Trans. and Eds.), Pratıtyasamutpādastutisubhāṣitahṛdayam of Ācārya Tsongkhapa. Dalai Lama's Tibeto-Indological Series (Vol. 3). Sarnath: CHITS.

Tsongkhapa Lobsang Dakpa (Tsongkhapa Blo bzang Grags pa). (1997). Essence of true eloquence discerning the definitive and the interpretive meaning (Drang ba dang nges pa' $i$ don rnam par byed pa'i bstan bcos legs bshad snying po DNLS). In Geshey Yeshes Thabkha's Shar Tsongkhapa blo bzang drags pas mdzad pa'r drang ba dang nges pa'i don rnam par byed pa'i bstan bcos legs bshad snying po. Sarnath: CIHTS.

Vasubandh. (1998). Commentary on the First Dependently arisen (Pratītyasamutpādādivibhañgabhāşya/ Rten cing 'brel bar 'byung ba dang po'i rnam par dbye bab shad pa, Mdo 'grel Chi 1b-61a). Sde dge edition of the Bstan 'gyur. Dharmasala: Paljor Press. 
Vasubandhu. (1991). Abhidharmakośa-bhāṣyam of Vasubandhu (L. de La Vallee Poussin (French), Trans. and L. M. Pruden (English)) (Vols. I-IV). Berkeley: Asian Humanities Press.

Walser, J. (2008). Nāgārjuna in context: Mahāyān Buddhism and early Indian culture. Delhi: Motilal Banarsidass Publishers Private Limited.

Yuvācārya Mahāprjñā. (1984). New Dimensions in Jaina Logic. Ladnun: Jaina Vishva Bharati. 